\title{
Studies on Hexokinase and Glucokinase in Rat Liver
}

II. Effects of Thyroid and Pituitary Hormones on the Enzyme Activity

\section{Noriyasu MORI}

(The Second Department of Medicine, Gifu University School of Medicine)

It was reported by the present author in the preceding paper that the increase in liver glucokinase (GK) activity in steroid-diabetic rats is presumed to arise through an oversecretion of insulin and also that cortisol does not inhibit the GK-inducing effect of insulin. The present work was undertaken to investigate possible effects of hypophysectomy, thyroidectomy, and thyroxine, ACTH and growth hormone administration on the GK and hexokinase (HK) activity of rat liver, and also to know whether or not administration of each of these hormones yields an antagonizing action on the GK-inducing effect of insulin.

1. Upon administration of thyroxine to normal rats, the liver HK activity was increased significantly, but the GK activity remained unchanged.

2. Following thyroidectomy, the GK activity showed a significant decrease, while the $\mathrm{HK}$ activity remained unaltered. When $\mathrm{T}_{4}$ was administered to such ectomized animals, the GK activity showed a tendency to restoration:

3. Growth hormone administration to normal rats did not bring any significant change in the activity of these two enzymes.

4. In the liver of hypophysectomized rats, the GK activity was significantly lower than normal. After growth hormone or ACTH administration to these animals, no tendency to the recovery of this enzyme activity was observed.

5. The decreased level of the liver GK activity in alloxan-diabetic animals was raised almost to the normal by insulin treatment, but simultaneous administration of $\mathrm{T}_{4}$ or of growth hormone together with insulin did not bring any enhancement in the increase. This result may indicate the fact that neither $\mathrm{T}_{4}$ nor growth hormone blocks the GK-inducing effect of insulin.

(See pp. 982 989) 


\title{
白鼠肝 Hexokinase, Glucokinase に関する研究
}

\author{
第二編 甲状腺ホルモンおよび下垂体ホルモンの影響について
}

岐阜大学医学部第二内科（担当：早瀬正二教授）

森矩 尉

本論文の要旨は第40回日本内分泌学会総会（昭和42年, 名古屋にて発表）

（昭和44年 9 月 1 日受付）

白鼠肝 Hexokinase, Glucokinase 活性の変動を下垂体摘出群, 甲状腺摘出群, 両群飞 growth hormone, thyroxin 単独わよび insulin 併用投与群につき検討し, insulin-dependent である GK 活 性に両ホルモンが如何なる影響を及ぼすがついて調べた。 thyroxin 投与でHK活性は有意に上昇し， growth hormone 投与では HK, GK 活性共に不変であつた. 又 insulin による GK 活性上昇を growth hormone, thyroxin 共に阻害効果を示さなかつた。

緒 言

甲状腺ホルモンの糖代謝におよぼす影響については，てのホルモンがブドウ糖の晹管よりの糖吸収を促進 し1), 糖尿病を悪化させ, 犬では膵の部分摘除に thyroxin を投与すると糖尿病を起てすととが知られてい $ろ^{2)}$. 又 Smith 等 ${ }^{3)}$ はラットに thyroxin 投与で筋肉中の Hexokinase (以下 HK と略す) 活性の上昇を 述べている. 一方 growth hormone の酵素に対する作用はその成長, 促進作用に関連して燐酸と蛋白代謝

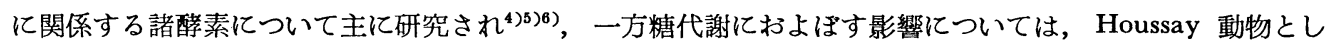
て有名な脳下垂体を摘出すると insulin感受性が高まり, 膵摘除により起した糖尿病が軽快するといわれて おり, 又最近 growth hormone 投与で insulin 過分泌の存在するてとが報告されている7889)1011). この様 に糖代謝と脳下垂体ホルモンおよび甲状腺ホルモンが密接な関係を示しているてとが明らかとされて来ると 共に，てれらホルモンが insulin-antagonist の一つとしても注目されて来た ${ }^{12) 13}$. 著者は前編でステロイ ド糖尿ラットでは insulin 過分泌を介して肝GK活性の上昇がくるものと推論し，又 cortisol は insulin によるGK活性の誘導効果を阻害しないととを報告した. 本研究ではとの HK, Glucokinase (以下GKと 略す) そおよぼす growth hormone, thyroxin（以下 $\mathrm{T}_{4}$ と略す）の影響を調べ，さらに insulin による GK活性上昇効果にてれらのホルモン投与が拮抗作用を示すか否かについても検討した.

I 、実験動物ならびに測定方法 :

\section{1. 実験動物}

体重200 g 前後の雄純系 Wistar rat を実験に供した。飼料はオリエンタル固型飼料（GE II 型）を用い, 実験前12時間絶食し水は自由に与えた。

\section{2. 動物の処置}

A. 脳下垂体摘出白鼠

シオノギ製薬研究所 (大阪) に依頼し外聴道法で下垂体摘出を行なつた. 実験終了後解剖し肉眼的に下垂 体の残存を認めないものを測定に用いた.

B. 甲状腺摘出白鼠 
エーテル麻酔下で前頸部に切開を加え甲状腺摘出を行なつた。実験終了後解剖し残存甲状腺重量が 1.4〜 $3.5 \mathrm{mg}$ 以下のものを測定に用いた。

G. アロキサン糖尿病白鼠

alloxan monohydrate (Sigma chemical Co.) を $145 \mathrm{mg} / \mathrm{kg}$ 宛筋注し 2 週間後尿糖陽性のものを使用し た.

D. Growth hormone 投与白鼠

0.5 U.S.P. Growth hormone (Raben type) units per mg (N.B.C) を用いた. (U.S.P. : United states pharmacopeia)

E. $T_{4}$ 投与白鼠

L-Thyroxin Sodium $30 \gamma$ 宛 1 日 1 回正常白鼠に筋注した.

F. 甲状腺摘出後 $\mathrm{T}_{4}$ 投与白鼠

甲摘後 3 日目より $\mathrm{T}_{4} 30 \mathrm{r}$ 宛 7 日間毎 7 日筋注したものを実験に供した。

\section{3. 酵素活性の測定}

HK, GK は Glucose-6-phosphate dehydrogenase-dependent spectrophotometric method を用い, Vinuela 等の変法に従つた。単位は室温 $\left(21.0 \sim 24.0^{\circ} \mathrm{C}\right)$ で 1 分間に $1 \mu$ mole の glucose の phosphorylation を肝 $1.0 \mathrm{~g}$ 湿重量, total liver 当り, $100 \mathrm{~g}$ body weight 当りにつき算出し統計的処理を行ない有意 差の検討を行なつた，血糖は Hagedorn-Jensen 法で測定した。

II. 実験成績 :

1. 正常および甲状腺摘出白鼠肝 $H K ， G K$ 活性におよぼす $T_{4}$ の影響について

Table 1 亿示された様に甲状腺摘出群では, 体重の減少, 血糖值の低下がみられ, 醉素活性では。 HK

Table 1. Effect of thyroxine and thyroidectomized on the activities of hexokinase and glucokinase in the livers

\begin{tabular}{|c|c|c|c|c|c|c|c|c|c|}
\hline \multirow{2}{*}{ Treatment } & \multirow{2}{*}{$\begin{array}{l}\text { Body } \\
\text { weight }\end{array}$} & \multirow{2}{*}{$\begin{array}{l}\text { Liver } \\
\text { weight }\end{array}$} & \multirow{2}{*}{$\begin{array}{l}\text { Blood } \\
\text { sugar }\end{array}$} & \multicolumn{2}{|c|}{ per g. of liver } & \multicolumn{2}{|c|}{ per whole liver } & \multicolumn{2}{|c|}{$\begin{array}{l}\text { per } 100 \mathrm{~g} . \\
\text { body weight }\end{array}$} \\
\hline & & & & $\mathrm{HK}$ & GK & $\mathrm{HK}$ & GK & $\mathrm{HK}$ & GK \\
\hline Normal & $\begin{array}{r}190.0 \\
\pm 7.1\end{array}$ & 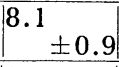 & $\begin{array}{c}114.6 \\
\pm 10.8\end{array}$ & $\begin{array}{l}0.14 \\
\pm 0.02\end{array}$ & $\mid \begin{array}{c}1.20 \\
\pm 0.52\end{array}$ & $\begin{array}{l}1.12 \\
\pm 0.14\end{array}$ & $\mid \begin{array}{l}9.48 \\
\pm 3.52\end{array}$ & $\left|\begin{array}{c}0.60 \\
\pm 0.08\end{array}\right|$ & $\begin{array}{l}4.96 \\
\pm 1.80\end{array}$ \\
\hline $\begin{array}{r}\text { Normal + Thyroxine } \\
(3)\end{array}$ & $\begin{array}{r}173.3 \\
\pm 26.2\end{array}$ & $\begin{array}{r}6.9 \\
\pm 0.8 \\
\end{array}$ & $\mid \begin{array}{c}121.4 \\
\pm 8.7\end{array}$ & $\left|\begin{array}{rr}0.28 & * * \\
\pm 0.02\end{array}\right|$ & $\begin{array}{c}1.01 \\
\pm 0.24\end{array}$ & $\begin{array}{r}2.00 \\
\pm 0.32\end{array}$ & $\left|\begin{array}{l}7.16 \\
\pm 2.32\end{array}\right|$ & $\left|\begin{array}{ll}1.16 & * * \\
\pm 0.02\end{array}\right|$ & $\begin{array}{l}4.06 \\
\pm 0.83\end{array}$ \\
\hline Thyroidectomized & $\mid \begin{array}{c}153.3 \\
\pm 41.1\end{array}$ & $\begin{array}{r}7.0 \\
\quad \pm 0.9 \\
\end{array}$ & $\mid \begin{array}{rr}82.7 & * * \\
\pm 7.4\end{array}$ & $\begin{array}{c}0.14 \\
\pm 0.04\end{array}$ & $\begin{array}{r}0.66 \\
\pm 0.04\end{array}$ & $\mid \begin{array}{l}0.96 \\
\pm 0.28\end{array}$ & $\begin{array}{r}4.68 \\
3 \\
40.79\end{array}$ & $\left|\begin{array}{c}0.66 \\
\pm 0.14\end{array}\right|$ & $\begin{array}{l}3.16 \\
\pm 0.50\end{array}$ \\
\hline $\begin{array}{l}\text { Thyroidectomized + } \\
\text { Thyroxine }\end{array}$ & $\begin{array}{c}153.3 \\
\pm 9.4 \\
\end{array}$ & \begin{tabular}{|r|}
6.5 \\
\\
\end{tabular} & $\begin{array}{c}128.3 \\
\pm 2.7 \\
\end{array}$ & $\begin{array}{c}0.18 \\
\pm 0.04 \\
\end{array}$ & $\begin{array}{c}0.88 \\
\pm 0.30 \\
\end{array}$ & $\begin{array}{l}1.18 \\
\pm 0.14\end{array}$ & $\begin{array}{r}10.64 \times \times \\
\pm 2.02 \\
\end{array}$ & $\begin{array}{l}0.78 \\
\pm 0.14\end{array}$ & $\begin{array}{l}7.50 \quad x \times \\
\pm 2.12\end{array}$ \\
\hline
\end{tabular}

Each value indicate mean $\pm \mathrm{SD}$

$*: \mathrm{P}<0.05$

$* *: \mathrm{P}<0.01$

$* *: \mathrm{P}<0.01$ (for thyroidectomized rats)

( ) : indicates number of rats

は著変を示さなかつたが，GK活性値の有意の低下（P<0.05） を示した．乙の摘出群に術後 3 日目より $\mathrm{T}_{4}$ $30 \gamma$ 宛 7 日間筋注すると, HK, GK 共に活性増加の傾向を示した. 一方正常群に $\mathrm{T}_{4} 30 \gamma$ 宛 1 週間筋注す ると, 体重, 血糖值は不変であるが, $\mathrm{HK}$ 活性值の有意の上昇 $(\mathrm{P}<0.01)$ を示したが, $\mathrm{GK}$ 活性值は不変 であつた． $\mathrm{HK}$ は $\mathrm{T}_{4}$ に良く反応しているてとを示している.

2. アロキサン糖尿病白鼠肝 HK，GK 活性におよぼす $\mathrm{T}_{4}$ とInsulin の影響について

内因性 insulin 久乏と考えられるアロキサン糖尿病白鼠肝を用い， $\mathrm{T}_{4}$ と insulin のHKおよび GK 活 性值におよぼす影響について調べた。アアロキサンで著减したGK活性は insulin で復活がみられたが，ア 
ロキサン筋注 14 日目より $\mathrm{T}_{4} 30 \gamma$ 宛 3 日間筋注すると，HK 活性は正常と比べて著変ないが $(0.10 \pm 0.04)$,

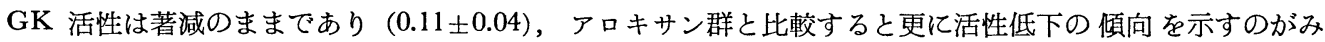
られた。 とのような動物に insulin $4 \mathrm{U} /$ 日 と $\mathrm{T}_{4} 30 \gamma$ を併せ 3 日間筋注すると低下した $\mathrm{GK}$ 活性值の復 活がみられ，しかもアロキサン筋注群に insulin 投与した場合と同程度の活性復活を示している. (Fig. 1)

Fig. 1. Effect of thyroxin and growth hormone on liver glucokinase induction by insulin in alloxan diabetic rats (hexokinase and glucokinase activity is expressed as moles of TPNH formed per mnute gram liver)

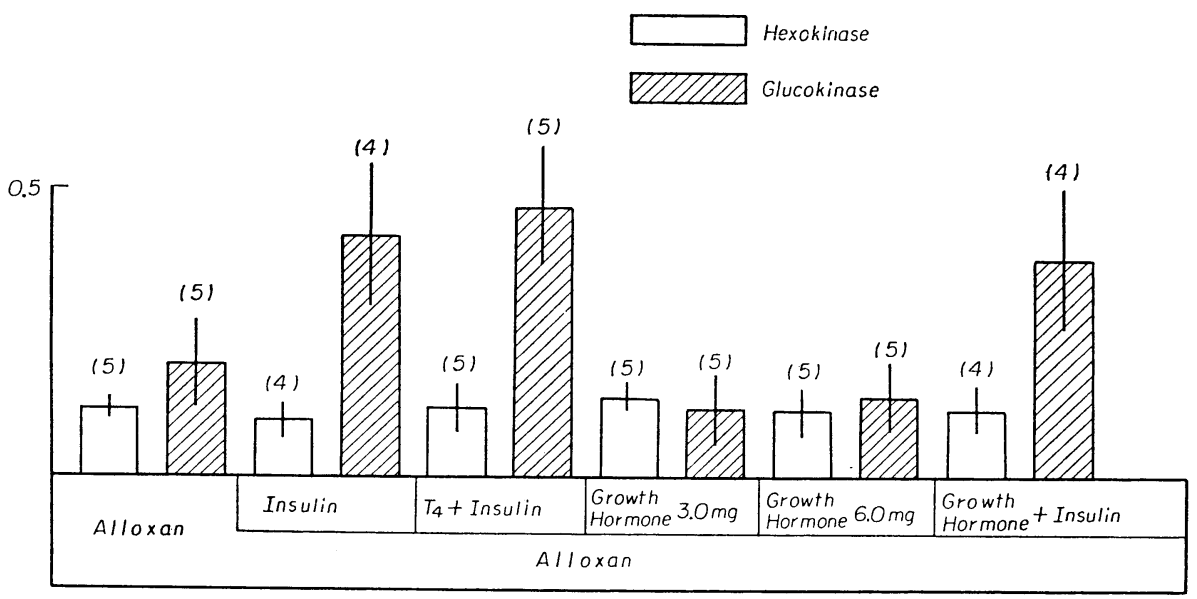

3. 正常および下垂体摘出白鼠におよぼす Growth Hormone, ACTH の影響について

下記処置群について体重, 肝重量, 血糖値および醳素活性を調べた。

1. 下垂体摘出後 10 日目

2 .下垂体摘出後 7 日目より growth hormone $3.0 \mathrm{mg}$ 宛毎日 10 日間筋注

3 . 正常白鼠传 growth hormone $3.0 \mathrm{mg}$ 宛10日間筋注

4. 下垂体摘出後 7 日目より ACTH 2.0U 宛10日間筋注

5. 下垂体摘出後 7 日目より growth hormone $3.0 \mathrm{mg}$ と AGTH 2.0U 宛10日間併せ筋注

正常および下垂体摘出動物の10日關の体重の増加率を百分率で表はすと，正常群では+41.7 18.1\%であ り，下垂体摘出群では全く体重の増加がみられねい. 又正常動物に growth hormone 在投与しても体重増 加はわずかに認められたにすぎないが (5.0土1.3)，下垂体摘出群に growth hormone を投与すると正常 群はどでないが体重増加がみられた（18.2土1.1）。酵素活性については，Table 2 に示される様に，下垂 体摘出でHK活性は著変しないが，GK活性は有意に低下し $(\mathrm{P}<0.01)$, total liver, 100g body weight で も著堿がみられ，growth hormone 投与でわずかに活性值の回復がみられたが有意ではない，一方正常白 鼠に growth hormone を投与すると，HK活性もGK活性も共にやや低下の傾向を示したが有意の変化で はない. 次に下垂体摘出白鼠に摘出術後7 日目より AGTH 2U 宛10日間筋注すると体重，血糖わよび肝重 量は有意に上昇したが，HKおよびGK活性は著変しなかつた。 又摘出動物に growth hormone $3.0 \mathrm{mg}$ と ACTH 2U 宛10日日間併せ筋注すると，体重，肝重量は更に有意の上昇を示し $(\mathrm{P}<0.01)$, 又血糖値もやや 増加の傾向を示したが, HKおよびGK活性は不変であつた.

4.アロキサン糖尿病白鼠におよぼす Growth hormone と Insulin の影響について

内因性 insulin 欠乏と考えられるアロキサン糖尿病白鼠を用い, growth hormone と insulin のHKお よびGK活性におよぼす影響について調べてみた。アロキサン筋注後尿糖陽性のものに14日目より growth 
Table 2. Effect of growth hormone and ACTH on the activities of hexokinase and glucokinase in the liver of normal and hypophysectomized rats

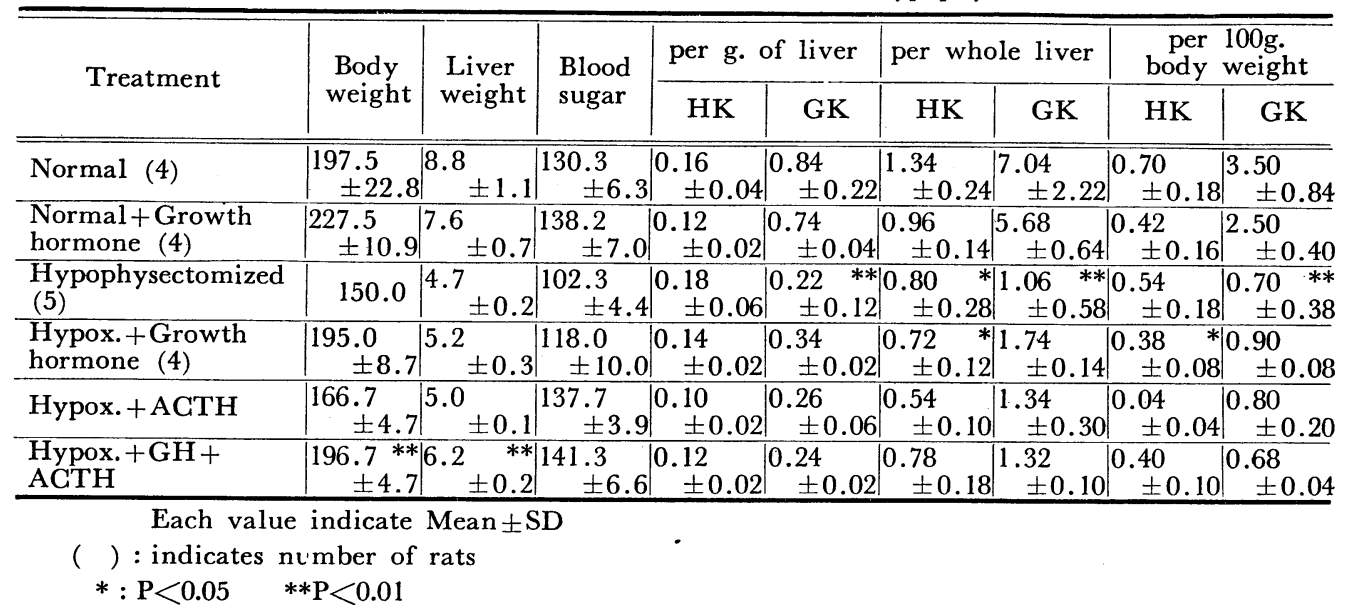

hormone 3.0, 6.0mg 宛 3 日間筋注すると, 体重 $(161.0 \pm 8.5,170.0 \pm 7.8)$ 肝重量 $(8.2 \pm 1.0,8.0 \pm 0.5)$ 共に著変ないが血桾側はやや増加を示した，酻素活性は正常群に比し HK活性は著変しないが，GK活性の 著しい低下を示したが，アロキサン群と比較するとHK活性は不変であるが，GK活性は有意でないが活性 低下を示している. (Fig. 1) しかし growth hormone の投与量の間には活性值の差はみられなかつた。次 にアロキサン処置後14日目より growth hormone $3.0,6.0 \mathrm{mg}$ と insulin $4.0 \mathrm{U} 3$ 日間併せ筋注すると, ア ロキサン群に比し体重 $(175.0 \pm 8.7,164.0 \pm 25.5)$, 肝重量 $(9.2 \pm 1.1,8.0 \pm 0.9)$ は有意差を認めないが

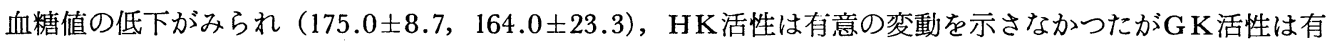
意 $(P<0.01)$ 飞活性復活を示している. しかし growth hormone の投与量によつて差はみられなかつた. アロキサンに insulin 投与した場合に比べて有意の差はみられなかつた.

考察

Growth hormone, $\mathrm{T}_{4}$ および ACTH の解糖系諸醳素活性におよぼす影響については古くから多くの報 告があるが3(14)15)16), 肝 $\mathrm{HK}, \mathrm{GK}$ 活性についての報告は極めて少ない(17)18199. そてでてれらの木ルモンの HKおよびGK活性におよぼす効果について考察を加え，併せててれらホルモンとインスリンの関係を少し く述べてみよう。

\section{1.甲状腺ホルモンの影響}

甲状腺ホルモン投与では $\mathrm{GK}$ 活性には著変をみないが， HK活性の上昇がみられ，甲状腺摘出では $\mathrm{GK}$ K活 性の著明な低下がみられる (Table 1)。乙のホルモン欠员状態でのみ G K 活性が変動するてとは, 甲状腺ホ ルモンがての酵素に直接影響するのではなく機能低下の結果の他の因子を介している可能性が考劣られる. すなわち甲状腺機能低下においては腸管の糖吸収は低下し，血糖值も低下を示しての時 insulin の必要量 も少いものと考えられる.すでに述べて来た絶食時の本酵素活性の低下を考虑すれば，ての場合の活性低值 も腸管の吸収障害に起因する二次的な変化も重要な因子と考えられる，一方肝 $\mathrm{HK}$ 活性が $\mathrm{T}_{4}$ 投与で上昇す るととは興味深い。乙のようにT 4 投与でHK活性の上昇することは，Smith 等 ${ }^{3)}$ は白鼠筋で, Nishikawa 等 ${ }^{18) 19}$ は腸粘膜で認めているがその作用機序については未だ分らない，近年インスリン測定が可能となり， thyroxin 投与または甲状腺機能立進症での insulin 分必克進を認める報告がみられる。 ${ }^{2021)}$ 著者のてれま での成績からも insulin-dependent のGK活性は thyroxin 投与で活性上昇を認めてもよいようであるが， Table 1 に示されたように正常白鼠に thyroxin 投与で活性上昇は認められなかつた。これは何らかの 
insulin 効果の阻害因子が働くためか，あるいはまた，Cohen ${ }^{22)}$ ，Elgee ${ }^{23)}$ 等のいうような insulin 破壊促進 によるものであろうか.

\section{2.下垂体ホルモンの影響}

正常白鼠に growth hormone 投与を行なつても肝 $\mathrm{HK}, \mathrm{GK}$ 活性は著変を示さないが，下垂体摘出では GK活性の著减がみられた。乙の摘出白鼠でGK活性の低下がみられることは，growth hormone による 蛋白同化作用の欠除之共に TSH 欠除による腸管の糖吸収低下の結果, insulin 必要量の減少によるものか, 又 ACTH を介す副腎系の作用の欠除による二次的なものが考えられる．次に内因性 insulin 欠乏と考元 られるアロキサン糖尿病白鼠に growth hormone を投与するとGK活性の低下がみられるととは, ての木 ルモンが insulin 欠乏時には糖尿状態の増要に作用する可能性を示している. 最近 growth hormone 投与 についても insulin 過分化が認められるとの報告が多くみられるようになつた ${ }^{7889) 10)}$. 従つて growth hormone 投与でも GK活性值の上昇の可能性が考光られるが, Table 2 に示された様に, 正常群と比較し 有意の変化を示さなかつた。 また下垂体摘出動物で低下している GK 活性に対して, growth hormone, ACTH 両ホルモンの単独又は併用投与でもその活性回復のみられない成績より，てのホルモン以外の因子， 例えば TSH などがより重要な因子である可能性が考えられる. 又下垂体摘出動物の術後の食䬣摂取が充 分でないととも大きな要因であろう，又下垂体摘出動物でのHK活性は一般に低下の傾向を示している点も 注目される.

\section{Insulin による GK 誘導効果亡 Growth hormone, $\mathrm{T}_{4}$ の関係}

前編で cortisol は insulin によるGK活性の誘導効果を阻害しないてとを報告したが，Fig. 1 にみられ るように， $T_{4}$ 投与も growth hormone 投与もともに insulin による本酥素活性上昇効果を阻害しなかつ た. growth hormone, $\mathrm{T}_{4}$ は insulin 拮抗ホルモンのうちに数光られるが, いづれも insulin によるGK 誘導効果には阻害に働かないものと思われる。

\section{結語}

糖利用の第一段階を受け持つ Hexokinase, Glucokinase 活性におよぼす脳下垂体摘出, 甲状腺摘出の影 響, thyroxin, ACTH および growth hormone の影響とてれらホルモンと insulin の関係について調べ た.

1）正常白鼠に thyroxin 投与でHK活性は有意に上昇したが，GK活性は不変であつた。

2) 甲状腺摘出を行なうと G K 活性は有意に低下を示したが， $\mathrm{HK}$ 活性は不変であつた。摘出動物に $\mathrm{T}_{4}$ を投与すると, HK, GK 活性の復活の傾向がみられた。

3) 正常白鼠䎲 growth hormone 投与では, HK, GK 活性は共に有意の変化をみなかつた.

4 ）脳下垂体摘出白鼠肝GK活性は有意に低下し，乙の動物に growth hormone, ACTH を投与しても G K 活性の復活はみられなかつた。

5）アロキサン糖尿病動物に insulin 投与を加えると GK 活性の上昇をみるが，乙の条件で $\mathrm{T}_{4}$ 又は growth hormone を insulin 投与に加えても, 本酵素活性上昇の程度は変らなかつた。 $\mathrm{T}_{4} も$ growth hormone も共に insulin によるGK誘導効果を阻害しないと考光られる結果をえた。

終りに臨み, 御校閲を睗わつた早瀬正二教授, 御助言を睗わつた木島滋二前教授, 長崎大学法医学教室須 山弘文教授に深謝するとともに，終始御指導御鞭涟を睗わつた京都大学老年医学教室竹内三郎助教授に深謝 する。また法医学教室沢田英夫助教授の御教示，御助言に感謝する。

\section{文献}

1) Althausen, T.L. and M. STOGKholm : Amer. J. Physiol., 123 : 577, (1938). 
WILLIAMS-ASHMANN : Biochem. Biophys. Acta., $7: 295$, (1951). C.H. LI and H.M. EVANS : Arch. Biochem. Biophys., $31: 168$, (1951). P.D. and M. GLYNN : J. Biol. Chem., $187: 261$, (1950). $73: 61$, (1959). Med., $105:$ 455, (1960). 7) ZOHND, G.R., J. STEINKE and A.E. RENOLD : Proc. Soci. Exp. Biol. GAMPBELL, J., K.S. RASTOGI and H.R. HAUSLER : Endocrinology, $79: 749$, (1966). 8) IKKOS, D. and R. LUFT : Lancet, $2: 897$, (1967).

4) GESCHWIND, I.I., 5) BARTLETT, CAMPBELL, J. and K.S. RASTOGI : Diabetes, $15: 30$, (1966).

11) RANDLE, P.L. and F.G. YOUNG : J. Endocrin., $13: 335$, (1956). J.A. BURGESS : Diabetes, $15: 905$, (1966). 12) RABINOWITZ, D., T.J. MERIMEE and (1963). 14) HARARY, I. : Biochem. Biophys. Acta. $29: 647$, (1958). 13) YOUNG, F.G. : Endocrinology, $73: 654$, G.E., McLEAN and J.K. WHITHAEAD : Biochem. J., 63, 520, (1956). M.J., and E.G. BALL : J. Biochem. Chem., 231 : 31, (1958). CORI and M.W. SLEIN : J. Biol. Chem., $168: 583$, (1947). Endocrinology, $68: 850$, (1961). 19) NISHIKAWARA, M.I. and E. GABRIELSON : Endocrinology, $68: 855$, (1961). 21）三宅 儀：糖尿病, $4: 37,(1961)$. 20) BULFOUR, W.M. : Amer. J. Med., $7: 596$, (1949). (1957). 23) ELGEE, N.T. and R.H. WILLIAMS : Amer. J. Physiol., $180: 13$, (1955). 